\title{
FINANCIAL DEVELOPMENT AND ECONOMIC GROWTH: A STUDY FOR OECD COUNTRIES IN THE CONTEXT OF CRISIS
}

MIRDEC-8TH INTERNATIONAL ACADEMIC CONFERENCE ON SOCIAL SCIENCES, ECONOMICS, BUSINESS AND FINANCES STUDIES

M. Carmen Blanco-Arana University of Malaga c.blancoarana@uma.es

\begin{abstract}
The aim of this paper is to study the relationship between economic growth and the main determinants of financial development in developed countries during the period 1990-2016. Using a random effects model, we provide empirical evidence of different aspects of financial development in order to show which of these characteristics of financial development help to explain economic growth in developed countries, particularly in OEDC countries in terms of finances through a panel data model and a dynamic model for the period examined. Paying special attention to the main determinants of the financial system and verify their influence on economic growth even when we control for other key country-level factors relating to economic growth. We conclude that an increase in domestic credit provided by financial-sector, in market capitalization and in the turnover ratio of domestic shares entails a significant positive effect on the GDP per capita. Among other socioeconomic determinants related to economic growth, expenditure in education, the inflation and unemployment rates seem highly significant in the economic growth of the analysed countries.
\end{abstract}

Key words: Financial development; crisis; economic growth; panel data; random effects model

JEL: G0, O1, O47 